\title{
MRS MOLLY LEVY — PRESIDENT SOUTH AFRICAN SOCIETY OF PHYSIOTHERAPY
}

Mrs Levy was elected President of the Society at the National Council Meeting held in Cape Town in April 1979. By unanimously electing her to this office, the highest of the Society, the Physiotherapists of South Africa expressed the esteem with which they regard her.

This is the first time that a Physiotherapist had held this position since the adoption of the present Constitution of the South African Society of Physiotherapy in 1955. Early in 1948 Mrs Levy was elected a member of the then Central Executive Committee of the South African Society of Physiotherapists. From 1949 to 1951 she was the assistant General Secretary of the Society. Following the change of the Constitution in 1955 she was elected Honorary General Secretary of the South African Society of Physiotherapy, a position she held Intil 1969 when she was elected First Vice-Chairman. From 1973 to 1979 she held the position of National Chairman. During these years the Society grew in strength and developed in many important ways, raising the status of the profession in this country.

One of the most far-reaching developments was the establishment of the Professional Board of Physiotherapy in 1973. Mrs Levy was elected Vice-Chairman of the First Board and Chairman of the second Board clested in 1978. Mrs Levy played a leading role in the achievement of compulsory registration for physiotherapists and in the establishment of prescribed areas tor physiotherapists. Under her chairmanship of the Society. greater representation was afforded all members through the establishment of the National Committee of Representatives, which meets twice a year, and the formation of Special Interest Groups with in the Society.

While holding her various offices in the Society, Mrs Levy actively promoted continuing education by her skillful management of visits by overseas lecturers A keynote of these tours was that the smaller branches of the Society were always included. Mrs Levy has always played an important part not only in national but also in international physiotherapy affairs. Between 1959 and 1974 she was our voting delegate on the World Confederation of Physical Therapy, attending many meetings in various parts of the world. In 1974 ne was elected a member of the Executive Comnittce of W.C.P.T. During these years she earned the very real respect of her colleagues in W.C.P.T. The South African Society of Physiotherapy could have no better example of professionalism and service than that of our President.

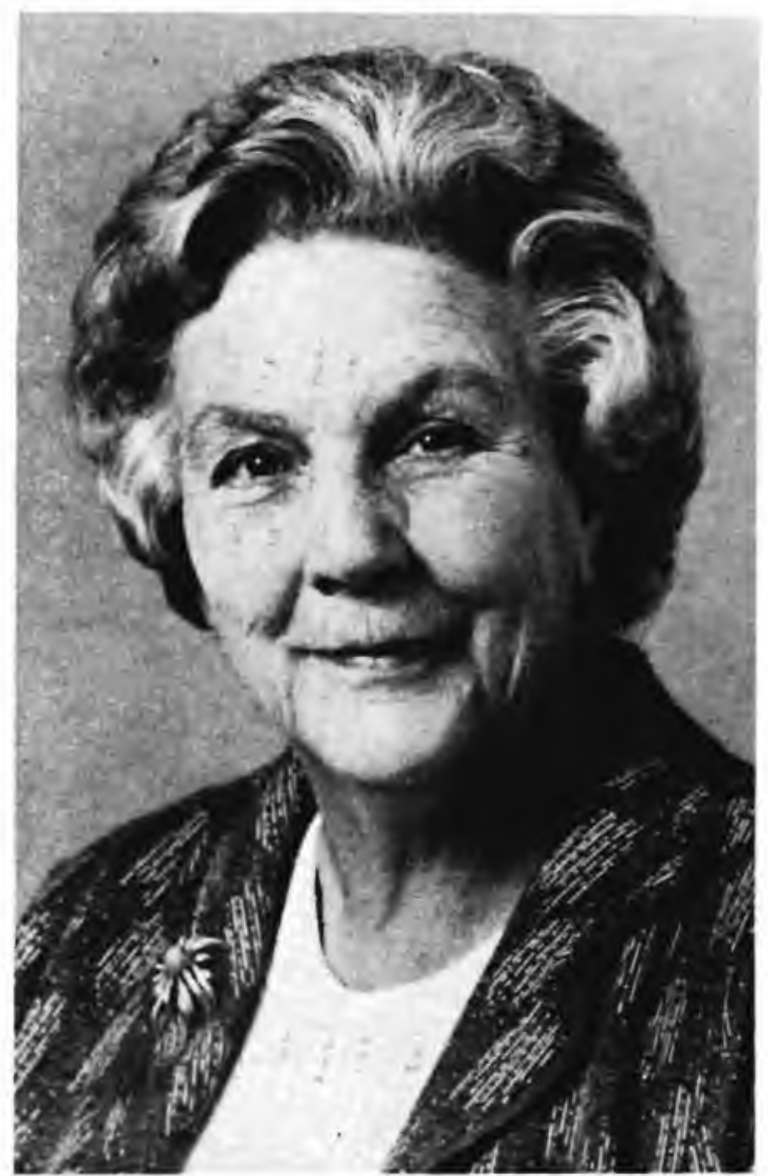

\section{Contents - Inhoud}

Openıng address 13th National Council Meeting ... 60

The Neurosurgeon and Chronic Pain ... ... ... 62

The Attitude of the Medical Profession to Chiro practic

Some Advances in Perinatal Care ... ... ... ... 71

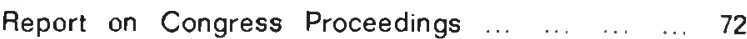

Report on 13th General Meeting of National Council 74

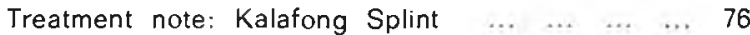

Treatment note: Graphic Representation of Muscle $\begin{array}{lllllllllll}\text { Strength } & \ldots & \ldots & \ldots & \ldots & \ldots & \ldots & \ldots & \ldots & \ldots & 77\end{array}$

Ongoing Research Projects $\ldots$..

$\begin{array}{llllllllll}\text { Branch News } & \ldots & \ldots & \ldots & \ldots & \ldots & \ldots & \ldots & \ldots & 79\end{array}$

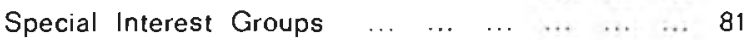

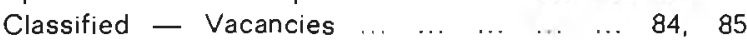

